\title{
GOVERNMENT POLICIES FOR ECOTOURISM DEVELOPMENT IN MANGROVE FORESTS OF IRAN
}

\begin{abstract}
Ecotourism development in mangrove forests requires comprehensive and detailed plans to consider all aspects of ecotourism development and maintaining of the ecosystem. Ecotourism development in every region has benefits, costs, opportunities and risks. Considering all cases, the need for convenient and accurate way to analyze the situation and take appropriate decisions. However, without careful planning and management that balance ecological, social, and economic objectives, it may lead to environmental damage. In order to achieve a pre-defined process, analytic network process method will use. The quantification using BOCR-interval arithmetic modeling will perform in association with analytic network process (ANP) via consensus of multiple experts. The results of a comprehensive review of the development of ecotourism in mangrove forests showed that development of ecotourism is preferred to non-develop ecotourism. However, there are serious risks on the balance of the ecosystem and environmental hazards.
\end{abstract}

Keywords: ecotourism, government, policies, mangrove forests.

\section{Introduction}

Development and enhancing tourism without guiding framework and pre-determined strategies for achieving development goals and in ad hoc manner is impossible. Adopting strategic planning to tourism development is necessary, because most of the times after observation and emersion of tourism development and undesired social and environmental effects, it takes a long time to alleviate the effects or control the process of development. Negative effects are usually because of the lack or inappropriateness of tourism development plans. So preparing tourism planning is necessary to compensate negative effects of tourism in destinations (Simpson, 2001). Strategic planning of tourism industry makes the governments able to recognize strengths, weaknesses, opportunities and threats and apply these findings for improving and enhancing the benefits of tourism industry. If exercised fit for the purpose, ecotourism is a means of protecting vulnerable ecosystems and which can create source for socio-economic development of the population residing within and around these areas (Kanen, 2006). Therefore, despite the benefits of development, identifying and minimizing the harms and risks of development should be considered in government policies.

\section{Literature Review}

Kenan (2006), used multiple criteria selected ecotourism planning activities in Igneada.. Fuller, (2005) has done the SWOT analysis and found that ecotourism provides potential for economic development through micro-enterprises to the Ngukurr, an indigenous community in northern Australia. Crispin and Wickham (2010) in the article titled as "Ecotourism and Strategic Management" emphasize on the link between strategic management research and issues such as environmental impacts, government policy and destination planning and marketing. In order to investigate the methods for synthesizing the composite priorities on each of the four BOCR factors, an arbitrary example was taken from Saaty involving the development of a condominium (Saati, 2007). We use the priorities of BOCR to weight and synthesize the overall weights of the alternatives obtained from the four merit structures.

\section{Hypotheses/Objectives}

The research hypothesis is that in the case of development of ecotourism in Iran's mangrove forest $\frac{B O}{C R}$ is greater than one.

\section{Research Design/Methodology}

International Journal of the Analytic Hierarchy Process
London, U.K.

August 4 - August 7, 2016 
The model is base on the analytical network process, i.e., on the combination with the benefits, opportunities, costs, and risks (BOCR) merit approach, with consideration of BOCR. Also included is a synthesizer that performs a BOCR calculation on the ANP control structure with feedback throughout the ANP control structure, to yield a result, which is proper according to ANP theory when values are non-trivial. In Super Decisions software, we first create a top-level network, which consists of a cluster containing the goal node and a second cluster containing the four merit nodes: Benefits (B), Opportunities (O), Costs (C) and Risks (R). There are some strategic criteria in the top-level network. The BOCR nodes have sub-networks attached to them. Each sub-network is a decision network: it contains a cluster with the specific merit goal and a cluster with the three alternatives.

\section{Data/Model Analysis}

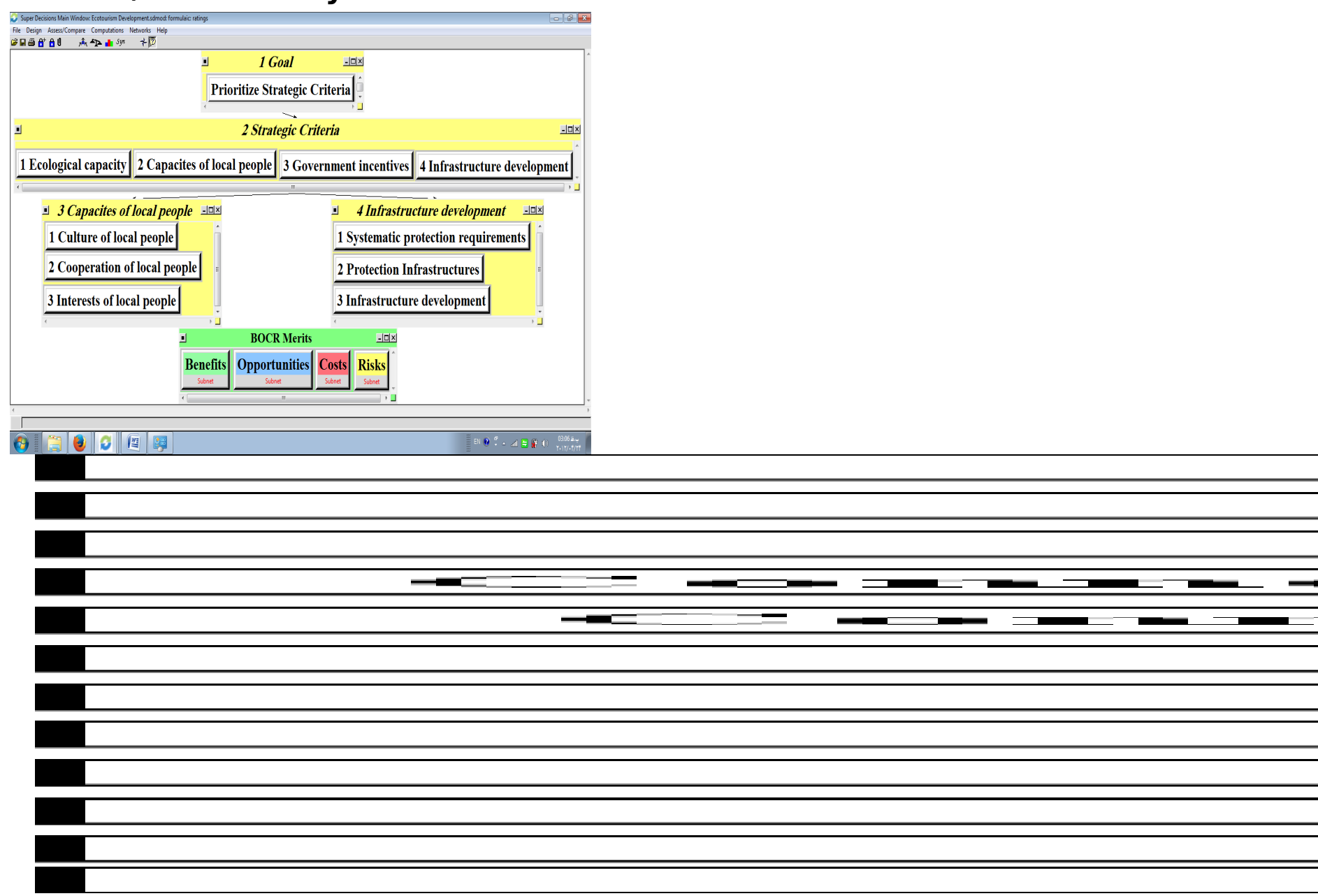

Fig. 1. The main model

Fig. 2. Outline of the methodology

Figure 2 shows the complete model. Notice that there are no inner or outer dependence or feedback links in the model, in conformity with the narrow focus of this note. This is one of the types of network model where "formulaic synthesis" is allowed using the predefined formulas.

\section{Conclusions}

The results of the determination of benefits, costs, opportunities and risks of the development of ecotourism in Mangrove forests showed, according to experts, as showed there are 48 important criteria for evaluating the effects of ecotourism development. Developed model in Superdecision software including three control
International Symposium of 
ISAHP Article: A Style Guide for Paper Proposals To Be Submitted to the International Symposium of the Analytic Hierarchy Process 2016, London, U.K.

criteria: socio-cultural, environmental and economic. The results of a comprehensive review of the development of ecotourism in mangrove forests showed development of ecotourism is preferred to nondevelop ecotourism. Preliminary results showed that economic benefits have greatest weight. However, there are serious risks on the balance of the ecosystem and environmental hazards because the weight of environmental costs was significantly high.

\section{Key References}

Crispin, S. and M. Wickham, (2010). Ecotourism and strategic management. University of Tasmania.

Fuller, D (2005) Ecotourism and Indigenous Micro-Enterprise Formation in Northern Australia Opportunities and Constraints. Tourism Management, 26(6), 891-904.

Kanen, O (2006). Multiple criteria activity selection for ecotourism planning in Igneada. Turkish Journal of Agriculture and Forestry, 30,153-164.

Saaty, T.L, (2007). Theory and Applicatioms of the Analytic Network Process, Decision Making with Benefits, Opportunities, Costs and Rrisks., RWS Publications, Pittsburgh.

Simpson, K, (2001). Strategic Planning and Community Involvement as Contributors to Sustainable Tourism Development. Current Issues in Tourism, 4(1), 3-41. 